\title{
The Prevalence of Paroxysmal Nocturnal Hemoglobinuria Clone in Adult Patients with Idiopathic Pulmonary Hypertension
} idiyopatik Pulmoner Hipertansiyonu Olan Erişkin Hastalarda Paroksismal
Noktürnal Hemoglobinüri Klonu Prevelansı

\author{
๑ Mesut Ayer, ๑ Tayfun Elibol*, • Ümit Yaşar Sinan**, ๑ Cengiz Bal***, \\ (1) Mehmet Serdar Küçükoğlu** \\ University of Health Sciences, Haseki Training and Research Hospital, Clinic of Hematology, Istanbul, Turkey \\ * Marmara University Pendik Training and Research Hospital, Clinic of Hematology, istanbul, Turkey \\ **Istanbul University Cardiology Institute, Department of Cardiology, Istanbul, Turkey \\ ***Osmangazi University Faculty of Medicine, Department of Biostatistics, Eskişehir, Turkey
}

Abstract

Aim: Paroxysmal nocturnal hemoglobinuria (PNH) a is a clonal disorder that may lead to several conditions such as thromboses, Budd-Chiari syndrome, renal failure, impotence, and pulmonary hypertension $(\mathrm{pHT})$. Since the presentation of $\mathrm{PNH}$ may be occult, monitoring for clonal evolution is recommended in certain situations including aplastic anemia, Myelodysplastic syndrome, and unexplained cytopenia, and thrombosis. The prevalence of PNH clone in patients with idiopathic $\mathrm{pHT}$ is unknown. We designed a study to determine the prevalence of $\mathrm{PNH}$ clone in patients with idiopathic pHT, since it may be the first isolated presentation of the disease.

Methods: A total of 45 patients with pHT were screened for PNH clone by proaerolysin conjugated with fluorescein.

Results: Only two out of 45 patients had elevated lactate dehydrogenase (LDH) levels at presentation. PNH clone was detected in none of the patients.

Conclusion: Screening for PNH clone in patients with $\mathrm{pHT}$, who have normal LDH levels is unnecessary.

Keywords: Paroxysmal nocturnal hemoglobinuria, pulmonary hypertension, clone
Amaç: Paroksismal noktürnal hemoglobinüri (PNH) tromboz, Budd-Chiari sendromu, böbrek yetmezliği, impotans, pulmoner hipertansiyon ( $\mathrm{pHT}$ ) gibi çeşitli hastalıklara sebebiyet verebilen klonal bir hastalıktır. PNH'nin prezentasyonu sessiz olabileceğinden, aplastik anemi, Miyelodisplastik sendrom, açıklanamaya sitopeniler ve tromboz gibi çeşitli durumlarda PNH klonu taranması önerilmektedir. İdiyopatik pHT'si olan hastalarda PNH klonu prevalansı ise bilinmemektedir. PNH'li hastalarda pHT hastalığın ilk bulgusu olabileceğinden, pulmoner hipertansiyonu olan hastalarda PNH klonu prevelansını belirlemek amacıyla bir çalışma tasarladık.

Yöntemler: pHT'si olan toplam 45 hastada florasanla konjuge proaerolizin yöntemiyle PNH klonu tarand.

Bulgular: Kırk beş hastanın yalnızca ikisinde başlangıç laktat dehidrogenaz (LDH) düzeyi normalin üzerindeydi. PNH klonu hiçbir hastada saptanmadı.

Sonuç: LDH düzeyi normal olan pHT hastalarında PNH klonu taranması gerekli görülmemiştir.

Anahtar Sözcükler: Paroksismal noktürnal hemoglobinüri, pulmoner hipertansiyon, klon

\section{Introduction}

Pulmonary hypertension (pHT) is defined as a mean pulmonary artery pressure (mPAP) $\geq 25 \mathrm{mmHg}$ at rest, measured by right heart catheterization. The initial symptoms of the disease result from an inability to adequately increase cardiac output during exercise. These include exertional dyspnea, lethargy, and fatigue. The progress of $\mathrm{pHT}$ leads to development of right ventricular 
hypertrophy and failure, producing right heart failure symptoms. PHT is now more common in patients with hereditary or acquired hemolytic anemia; this is probably related to increased awareness of $\mathrm{pHT}$ by physicians. Development of $\mathrm{pHT}$ is a poor prognostic indicator in patients with hemolytic anemia (1).

Paroxysmal nocturnal hemoglobinuria (PNH) originates from clonal enlargement of benign hematogenic stem cells that have gained a somatic mutation of the X-chromosome gene Phosphatidylinositol glycan anchor biosynthesis, class A (PIGA). This gene plays a role in the production of the glycosyl phosphatidylinositol (GPI) moiety that synthesizes some proteins to the cell surface. As a result of mutant PIGA, all mature cells (monocytes, erythrocytes, granulocytes, etc.) are deficient in all GPI-anchored proteins (GPI-APs). The clinical signs and the symptoms of $\mathrm{PNH}$ are hemolytic anemia, bone marrow (BM) failure and thrombosis (2). Patients may develop pHT and impaired renal function associated with hemoglobinemia in time.

Thrombosis in PNH patients is believed to be multifactorial and not completely understood, but like other symptoms of the disease, it is probably associated with lack of cell surface proteins (GPI proteins) and complement system activation. Indeed, $\mathrm{C} 5 \mathrm{a}$ is a proinflammatory mediator and may induce thrombosis. In addition, nitric oxide (NO) reduction (because of intravascular hemolysis and NO consumption) has been related to increased platelet aggregation and adhesion; also related to induced clot formation. Blood cells in PNH have no GPI-anchored urokinase receptor; as a result, fibrinolysis is also affected in PNH. Finally, tissue factor pathway inhibitor, a major inhibitor of tissue factor, has been proven to require a GPI-anchored chaperone protein for trafficking to the endothelial cell surface (3).

Many studies suggest that the reduction in NO content in microcirculation plays a direct role in the pathogenesis of disease-related symptoms through the mechanisms such as vasoconstriction, leukocyte adhesion, platelet activation, endothelial damage, and increased production of free oxygen. NO scavenging can also be the reason for the arterial spasm and related clinical manifestations. Eculizumab is a recombinant humanized $\operatorname{lgG} 2 / 4 x$ monoclonal antibody that binds to the complement C5 protein with high affinity, blocking the degradation of $\mathrm{C} 5$ protein to $\mathrm{C} 5 \mathrm{a}$ and $\mathrm{C} 5 \mathrm{~b}$, thereby preventing the formation of the terminal complement cascade C5b-9. This mechanism shows us the pathophysiology of $\mathrm{pHT}$ only in half of the patients. Therefore, other mechanisms besides NO consumption (such as pulmonary embolism) are thought to lead to $\mathrm{pHT}$ in PNH patients (4). However, data regarding the prevalence of $\mathrm{PNH}$ clone in patients with $\mathrm{pHT}$ is scarce.
In this study, we aimed to demonstrate the presence of any underlying PNH clones in patients with pulmonary arterial hypertension and chronic thromboembolic pHT.

\section{Methods}

\section{Patients}

A total of 45 patients with pHT were recruited in 2015. Age of patients varied between 18-90 years. Possible cause of pHT was idiopathic pulmonary arterial hypertension (IPAH) in 39 patients, chronic thromboembolic pHT in four patients, and $\mathrm{pHT}$ associated with connective tissue in two patients. All patients enrolled in the study were diagnosed with $\mathrm{pHT}$ by right heart catheterization and followed up by the İstanbul University Cardiology Institute pHT outpatient clinic.

\section{Inclusion and Exclusion Criteria}

Inclusion criteria goes as follows: mPAP $\geq 25 \mathrm{mmHg}$ at rest measured by right heart catheterization, endexpiratory mean pulmonary capillary wedge pressure $<15 \mathrm{mmHg}$, and pulmonary vascular resistance $>3$ Wood units. Exclusion criteria include mPAP $<25 \mathrm{mmHg}$ at rest measured by right heart catheterization, end-expiratory mean pulmonary capillary wedge pressure $\geq 15 \mathrm{mmHg}$, forced expiratory volume in 1 second/forced vital capacity ratio $<70 \%$ in respiratory function tests and/or history of other diseases accompanied by hypoxemia, any known diseases which may result in pHT such as Eisenmenger syndrome, sarcoidosis, myeloproliferative disorder, glycogen storage disease, etc., and any known diagnosis of $\mathrm{PNH}$.

\section{Paroxysmal Nocturnal Hemoglobinuria Clone}

PNH clone was detected by proaerolysin conjugated with fluorescein. $2 \mathrm{~mL}$ of peripheral blood from patients with $\mathrm{pHT}$ was collected into ethylenediaminetetraacetic acid tubes. Presence of PNH clone was studied from peripheral blood in the tubes which were kept at room temperature less than 24 hours. The PNH clone levels were studied within the year before the study.

Patient demographics, complete blood count, lactate dehydrogenase (LDH) levels, PNH clone levels and mPAP were reviewed retrospectively from the patient records.

Study assessments and methods were approved by the Taksim Training and Research Hospital Ethics Committee (dated 23.12.2015/approval no: 31). The study was conducted in accordance with the principles of the Declaration of Helsinki. Written informed consent was obtained from all patients for inclusion and publication of anonymized data.

\section{Statistical Analysis}

The Shapiro-Wilk test was used for determining the normal distribution of data. The independent Sample's 
t-test (t-test for independent samples) and Mann-Whitney $U$ test were used for group-wise comparisons. Chi-square tests were used for the analysis of categorical data. The data were summarized as mean \pm standard deviation and median (Q1; Q3). A p value of less than 0.05 was considered statistically significant.

\section{Results}

\section{Demographics}

The median age of 45 studied patients was 51 years (21-83). The minimum age was 21 years and the maximum age was 83 years for the participating patients. Thirty-four patients $(75.6 \%)$ were female. The patients with IPAH had a mPAP of $57.78 \mathrm{mmHg}$ with a minimum of $26 \mathrm{mmHg}$ and maximum of $115 \mathrm{mmHg}$. (Table 1).

\section{Paroxysmal Nocturnal Hemoglobinuria Clone}

No PNH clone was observed in any patients. As an indicator of hemolysis, LDH levels were evaluated: the IPAH group had a median of $203 \mathrm{U} / \mathrm{L}$ (N: 0-248 U/L). Only two patients with IPAH were observed to have a LDH level of two times or above the upper limit of normal.

\begin{tabular}{|c|c|}
\hline Variables & IPAH $(n=45)$ \\
\hline $\mathrm{mPAP}(\mathrm{mmHg})^{\mathrm{a}}$ & $57.78 \pm 20.49$ \\
\hline $6 \mathrm{MWT}(\mathrm{m})^{\mathrm{a}}$ & $344.65 \pm 136.23$ \\
\hline WBC $\left(\times 10^{3} / \mu \mathrm{L}\right)^{\mathrm{a}}$ & $7268.42 \pm 2007.43$ \\
\hline $\mathrm{HGB}(\mathrm{g} / \mathrm{dL})^{\mathrm{a}}$ & $13.16 \pm 2.02$ \\
\hline $\mathrm{HCT}(\%)^{\mathrm{a}}$ & $39.99 \pm 5.54$ \\
\hline Age, years ${ }^{b}$ & $51(39-61)$ \\
\hline Smoking (packs/year) ${ }^{b}$ & $0(0-1.5)$ \\
\hline $\operatorname{MCV}(f L)^{b}$ & $85.2(80.22-89.12)$ \\
\hline Platelets $\left(\times 10^{3} / \mu \mathrm{L}\right)^{b}$ & $208(161.25-246.50)$ \\
\hline $\mathrm{LDH}(\mathrm{U} / \mathrm{L})^{\mathrm{b}}$ & $203(177.25-225.75)$ \\
\hline Total bilirubin $(\mathrm{mg} / \mathrm{dL})^{\mathrm{b}}$ & $0.62(0.41-0.79)$ \\
\hline Indirect bilirubin $(\mathrm{mg} / \mathrm{dL})^{\mathrm{b}}$ & $0.36(0.23-0.48)$ \\
\hline $\mathrm{BNP}(\mathrm{pg} / \mathrm{mL})^{\mathrm{b}}$ & 770.50 (393.50-2619.50) \\
\hline PNH clone $(\%)^{b}$ & 0 \\
\hline \multicolumn{2}{|c|}{$\begin{array}{l}\text { BNP: Brain natriuretic peptide, HGB: Hemoglobin, HCT: Hematocrit, IPAH } \\
\text { Idiopathic pulmonary arterial hypertension, LDH: Lactate dehydrogenase, MCV } \\
\text { Mean corpuscular volume, mPAP: Mean pulmonary artery pressure, } 6 \mathrm{MWT} \text { Six } \\
\text { minute walk test, PNH: Paroxysmal nocturnal hemoglobinuria WBC: White blo } \\
\text { cell } \\
\text { Data were presented as amean } \pm \text { standard deviation or }{ }^{\mathrm{b}} \text { median (range) }\end{array}$} \\
\hline
\end{tabular}

\section{Discussion}

$\mathrm{pHT}$ is defined as a mPAP $\geq 25 \mathrm{mmHg}$ at rest, measured by right heart catheterization (1). The World Health Organization has classified pHT based upon etiology into the five groups. Pulmonary arterial hypertension is the most studied group and idiopathic and hereditary pulmonary arterial hypertension is very rare in the general population. Its prevalence is about 5-15 per million adults $(5,6)$.

$\mathrm{PNH}$ is a rare, acquired clonal hematopoietic stem cell disorder characterized by chronic intravascular hemolysis findings, BM failure and thrombosis, and the prevalence of the disease was considered to be 1-10 per million $(7,8)$. $\mathrm{pHT}$ is also very rare in patients with $\mathrm{PNH}$, yet there are no reports of prevalence. Free hemoglobin produced excessively during intravascular hemolysis may exceed the clearing capacity of haptoglobin, and as a result, a high level of free hemoglobin consumes endogenous NO (9). It also reduces the plasma arginine pool due to hemolysis as well as the increase in production of erythrocyte arginase 1 enzyme (which converts L-tryptophan, a substrate of NO synthesis, to ornithine) and reduces systemic use of $\mathrm{NO}$ (10). A decrease in NO level is associated with various sequelae such as development of systemic and pulmonary vascular resistance, $\mathrm{pHT}$ and disturbances in endothelial function and smooth muscle tone (9). pHT may occur in patients with $\mathrm{PNH}$ secondary to NO depletion in pulmonary circulation and/or due to pulmonary embolism (11). The cause of NO depletion is considered to be associated with intravascular hemolysis ("hemolysis-associated $\mathrm{pHT}^{\prime \prime}$ (12).

Hill et al. (3) performed a study in 2010 on 87 PNH patients to demonstrate the effect of eculizumab treatment on NO depletion associated with hemolysis; dyspnea and $\mathrm{pHT}$. The erythrocyte breakdown was determined by the serum LDH level. The mean LDH levels in the enrolled patients were observed to be $2229 \pm 1025$ U/L. A Doppler echocardiography (ECHO) was performed for 28 patients with hemolytic PNH in order to determine their pulmonary artery pressure which was found to be high in 14 of 20 patients with measurable treatment response (70\%). Mild to moderate $\mathrm{pHT}$ was observed in 12 patients $(60 \%)$ and moderate to severe $\mathrm{pHT}$ was detected in two patients $(10 \%)(13)$.

In another study by Hill et al. (13) in 2012, 29 patients with hemolytic PNH were examined for their cardiac functions by Doppler ECHO. The median age of the patients was 39.3 years; the median PNH duration was 3.2 years, and the median LDH level was observed to be 7.7 times the normal (mean $3133 \pm 385.6 \mathrm{U} / \mathrm{L}$ ). The basal granulocyte $\mathrm{PNH}$ and erythrocyte $\mathrm{PNH}$ clone levels were determined to be $92.1 \%$ and $32.5 \%$, respectively. An increased systemic pulmonary artery pressure was detected by Doppler ECHO in $36 \%$ of patients. The pHT prevalence of $36 \%$ may be explained by the hemolytic nature of the patients and the related significant decrease in NO levels.

The decrease in N-terminal brain-type natriuretic peptide (NT-proBNP) levels in patients for whom hemolysis 
was prevented by eculizumab treatment indicated a relationship between hemolysis and $\mathrm{pHT}$. It was observed that all 11 patients with $\mathrm{pHT}$ had increased hemolysis ( $\mathrm{LDH}>2 \mathrm{X}$ normal); no pHT was detected in patients with a LDH of $<2 \times$ normal, and the NT-proBNP levels were normal (13). Evidence explaining the frequency of $\mathrm{PNH}$ clone in patients with $\mathrm{pHT}$ was searched. Our study, to our knowledge, is the first to investigate $\mathrm{PNH}$ clone in IPAH and CTEPH patients. No PNH clone was detected in any of 45 enrolled patients.

Hill et al. (13) revealed that pHT was common in PNH patients with elevated LDH levels. In our study, only two patients were on the upper limit of normal LDH level. Our findings therefore suggest that there is no point to screen $\mathrm{PNH}$ clone for the etiology of $\mathrm{pHT}$ in patients with normal LDH levels.

\section{Conclusion}

In the light of current data, routine screening for $\mathrm{PNH}$ clone is not recommended for patients with IPAH and chronic thromboembolic PHT who have normal LDH levels and hemolysis tests.

\section{Authorship Contributions}

Surgical and Medical Practices: Ü.Y.S., M.S.K. Concept: M.A, Design: T.E. Data Collection or Processing: T.E. Analysis or Interpretation: C.B., T.E., M.A. Literature Search: T.E. Writing: T.E.

Conflict of Interest: No conflict of interest was declared by the authors.

Financial Disclosure: The authors declared that this study received no financial support.

\section{References}

1. Galiè N, Humbert M, Vachiery JL, et al. 2015 ESC/ERS Guidelines for the diagnosis and treatment of pulmonary hypertension: The Joint Task Force for the Diagnosis and Treatment of Pulmonary Hypertension of the European Society of Cardiology (ESC) and the European Respiratory Society (ERS): Endorsed by: Association for European Paediatric and Congenital Cardiology (AEPC), International Society for Heart and Lung Transplantation (ISHLT). Eur Heart J 2016;37:67-119.

2. Charles J. Parker. ASH Education Book December 10. Hematology 2011;1:21-9.
3. Hill $A$, Rother RP, Wang $X$, et al. Effect of eculizumab on haemolysisassociated nitric oxide depletion, dyspnoea, and measures of pulmonary hypertension in patients with paroxysmal nocturnal haemoglobinuria. $\mathrm{Br} J$ Haematol 2010;149:414-25.

4. Rother RP, Bell L, Hillmen P, Gladwin MT. The Clinical sequele of intravascular hemolysis and extracellular plasma hemoglobin: A novel mechanism of human disease. JAMA 2005;293:165362.

5. Humbert $\mathrm{M}$, Sitbon $\mathrm{O}$, Chaouat $\mathrm{A}$, et al. Pulmonary arterial hypertension in France: results from a national registry. Am J Respir Crit Care Med 2006;173:1023-30.

6. Ling $Y$, Johnson MK, Kiely DG, et al. Changing demographics, epidemiology, and survival of incident pulmonary arterial hypertension: results from the pulmonary hypertension registry of the United Kingdom and Ireland. Am J Respir Crit Care Med 2012;186:790-6.

7. Hernández-Campo PM, Almeida J, Acevedo MJ, et al. Detailed immunophenotypic characterization of different major and minor subsets of peripheral blood cells in patients with paroxysmal nocturnal hemoglobinuria. Transfusion 2008;48:1403-14.

8. Richards SJ, Whitby L, Cullen MJ, et al. Development and evaluation of a stabilized whole-blood preparation as a process control material for screening of paroxysmal nocturnal hemoglobinuria by flow cytometry. Cytometry B Clin Cytom 2009;76:47-55.

9. Borowitz MJ, Craig FE, Digiuseppe JA, et al. Guidelines for the diagnosis and monitoring of paroxysmal nocturnal hemoglobinuria and related disorders by flow cytometry. Cytometry B Clin Cytom 2010;78:211-30.

10. Gladwin MT, Sachdev V, Jison ML, et al. Pulmonary hypertension as a risk Factor for death in patients with sickle cell disease. N Engl J Med 2004;350:886-95.

11. Rother RP, Bell L, Hillmen P, Gladwin MT. The clinical sequelae of intravascular hemolysis and extracellular plasma hemoglobin: a novel mechanism of human disease. JAMA 2005;293:165362.

12. Schnog JJ, Jager EH, van der Dijs FP, et al. Evidence for a metabolic shift of arginine metabolism in sickle cell disease. Ann Hematol 2004;83:371-5.

13. Hill A, Sapsford RJ, Scally A, et al. Underrecognized complications in patients with paroxysmal nocturnal haemoglobinuria: raised pulmonary pressure and reduced right ventricular function. $\mathrm{Br} J$ Haematol 2012;158:409-14. 